\title{
Nous reptes, nous formats comunicatius
}

\section{Equip redactor de la revista Ciències (revista.ciencies@uab.cat)}

Acaba el 1r trimestre del curs 2013-14 amb els resultats de l'Informe PISA 2012, que un any posen damunt la taula un dels reptes que tenim com a comunitat de docents, investigadors i altres professionals de l'educació: contribuir a millorar l'ensenyament i aprenentatge de les ciències del nostre alumnat.

Per fer-ho, la innovació i la reflexió didàctica esdevé una eina més important que mai, i és per aquest motiu que la revista Ciències vol seguir contribuint a fomentar l'intercanvi d'experiències didàctiques, la discussió de reflexions sobre l'ensenyament $\mathrm{i}$ aprenentatge de les ciències, l'aprofundiment en el saber científic i el fet de compartir les iniciatives que engeguem en la nostra vida professional.

Després d'haver renovat el format de la revista durant l'any 2013 i d'haver-nos introduït en les xarxes socials, des de la revista volem proposar-vos a autors i lectors un nou format comunicatiu: els vídeo-articles.
Els vídeo-articles seran petits vídeos que acompanyaran als articles, i estaran gravats pels seus propis autors. És una experiència que ja s'ha començar a desenvolupar en altres revistes internacionals, com ara la coneguda "Physics Education", i que està tenint una gran rebuda. Així, a partir del proper número 27 oferirem als autors dels articles de la revista que ens enviïn voluntàriament un petit vídeo presentant el seu treball, que penjarem al Canal Youtube de la revista [1]. D'aquesta manera, volem contribuir a enfortir la comunitat de docents $\mathrm{i}$ professionals vinculats a l'ensenyament de les ciències, i a treure partir de l'ús de les xarxes socials, adaptant-nos als nous formats comunicatius cap als que va la nostra societat.

Des de l'equip de redacció de la revista us convidem a llegir aquest nou número 26 de la revista $\mathrm{i}$ us desitgem unes bones festes.

[1]

http://www.youtube.com/channel/UCYEr8CawR Q4rlkYGD4BrNMg/ 